\title{
ÉTICA, ECONOMÍA \\ Y PROSTITUCIÓN
}

\author{
FRANCISCO CAPELLA*
}

El ser humano es propietario pleno de sí mismo, de su mente y su cuerpo. Las personas pueden tener relaciones sexuales de cualquier tipo con quien libremente deseen si respetan la propiedad privada, si la relación es aceptada voluntariamente por las partes implicadas y nadie es agredido o estafado. Una persona puede proponer a otra las condiciones que desee para practicar el sexo, como por ejemplo una contraprestación económica. Es legítimo dar y recibir dinero a cambio de sexo, y sexo a cambio de dinero (o cualquier otro bien no monetario).

La legitimidad ética universal de la prostitución es diferente de su valoración moral para diferentes sensibilidades y culturas. Algunas religiones utilizan prostitutas sagradas en sus templos; algunas religiones defienden la castidad y la virtud, o consideran pecaminoso el sexo y repugnante la prostitución. Algunas personas pueden considerar a una prostituta como una fuente de placer y de conocimiento de técnicas sexuales; algunas personas pueden considerar que el sexo sólo es aceptable dentro del matrimonio, o como expresión de afecto, y sentir asco y repulsa respecto a la prostitución. Ninguna percepción moral legitima la prohibición estatal de la prostitución.

Defender con argumentos la legalidad de la prostitución no implica ser intelectualmente malvado ni tener intereses

(*) Miembro del Instituto Juan de Mariana. 
inconfesables en el asunto. Los que promueven la prohibición de la prostitución no son moralmente superiores ni necesariamente bienintencionados.

La prostitución no es un delito por ninguna de las partes, prostituta (hombre o más frecuentemente mujer) o cliente (mujer o más habitualmente hombre). Si la relación entre prostituta y cliente es voluntaria, su prohibición perjudica a ambos ya que les impide una relación que ambos desean. La criminalización de la prostitución provoca su marginación, la clandestinidad, aumenta su precio, dificulta los controles de calidad (por ejemplo sanitarios, facilitando la expansión de enfermedades de transmisión sexual), hace posibles abusos de los policías (algunos deben ser sobornados con dinero o sexo gratuito) y fomenta la existencia y el enriquecimiento de grupos criminales (acostumbrados a quebrantar la ley y a esclavizar personas) que la controlan en un mercado negro.

La persona que se prostituye puede trabajar por libre de forma autónoma, puede integrarse como asalariada en una empresa de servicios sexuales (con un contrato laboral que especifique las condiciones de su actividad) o puede contratar con un especialista la protección y gestión de su actividad. El proxeneta no es un delincuente si su relación con la prostituta es voluntaria y no violenta (puede protegerla de clientes potencialmente peligrosos o servir de intermediario captador de clientes); prostitutas con más experiencia pueden ejercer como empresarias para quienes otras prostitutas trabajen como asalariadas (con sueldos fijos o comisiones variables) o asociadas. Criminalizar a todos los proxenetas implica dificultar que las prostitutas se organicen y defiendan libremente.

Obligar por la fuerza a otra persona a ejercer la prostitución es un delito equivalente a una violación indirecta (sexo no consentido) y un robo (si se apropia de lo que paga el cliente). Igual que un cliente puede seleccionar qué prostituta desea, una prostituta puede negarse a mantener relaciones sexuales sin 
más explicaciones, excepto si ello implica un incumplimiento de un contrato legítimo previo. La mujer no es necesariamente la parte más débil. Una prostituta no es siempre una víctima. Para algunas la prostitución es sólo un trabajo (o una oportunidad esporádica de ganar dinero de forma ocasional), una forma de obtener riqueza más interesante que otras alternativas menos atractivas.

Las prohibiciones, regulaciones o restricciones estatales a la actividad sexual son violaciones de la propiedad privada individual típicas de autoritarismos conservadores o colectivismos violentos que pretenden imponer por la fuerza su moral arbitraria particular, y dañan a todas las partes que están dispuestas a mantener relaciones sexuales libremente consentidas. Algunas leyes son tan arbitrarias y absurdas que prohíben la prostitución pero permiten la pornografía, en la cual no sólo hay sexo a cambio de dinero sino que además se filma y se difunde ampliamente. No son nada extraños los casos de individuos hipócritas que condenan en público la prostitución pero se sirven de ella en privado.

Basar la prohibición de la prostitución en la dignidad del ser humano o la degradación de la mujer es tratar a las mujeres como un colectivo uniforme, o quedarse en una idea abstracta disociada de la realidad concreta. Cada mujer es un ser humano diferente, con sus preferencias subjetivas y sus capacidades específicas. Lo que para una persona es denigrante para otra puede ser algo placentero, o algo molesto pero que merece la pena por lo que se obtiene a cambio.

La prostituta ha sido a menudo insultada y vilipendiada. El hombre acusa a la mujer infiel (o que no desea relaciones sexuales con él) de ser una puta; el indeseable es un hijo de puta. A menudo los clientes exigen confidencialidad y discreción porque no quieren que se sepa que utilizan los servicios de prostitutas. Algunas prostitutas asumen su condición y que ésta sea conocida; otras prefieren mantener una imagen falsa para 
evitar el estigma social. El hombre suele ser celoso y difícilmente acepta emparejarse o casarse con una mujer que practica el sexo con otros.

Algunos hombres presumen de utilizar prostitutas, otros prefieren mantenerlo en secreto. Algunos se sienten culpables (si son creyentes religiosos pueden vivirlo como un pecado), otros lo asumen con más naturalidad. Algunas personas desprecian a los hombres que utilizan los servicios de las prostitutas, creen que lo hacen por sentirse machos fuertes y dominadores, que no pueden controlar sus necesidades fisiológicas, que son egoístas miserables y compulsivos que sólo buscan su placer personal sin preocuparse del bienestar ajeno. Algunos creen que la prostituta necesita humillarse para ejercer su actividad y que esto conlleva un inevitable e irreversible deterioro físico y psicológico (hay que prohibir la prostitución, aunque sea voluntaria, por el presunto bien de la prostituta que ella misma no conoce o conoce peor que el ingeniero social). Algunos creen que la prostitución es una forma de dominación masculina, pero entonces el pago monetario no tendría sentido. Algunos hombres pueden utilizar prostitutas por comodidad (prefieren pagar a probar a seducir a una mujer, lo cual no tiene garantías de éxito especialmente si el hombre no es atractivo), por timidez (se evita el dolor del rechazo) o simplemente por evitar la soledad (se paga más por la compañía que por el sexo).

Algunas prostitutas pueden sentirse molestas por lo que otras personas piensan de ellas o por la mala imagen de su profesión, por un posible estigma o repudio social. Las prostitutas no tienen derecho a controlar las mentes de las demás personas, a decidir qué es adecuado que piensen de ellas. No pueden pretender mantener un honor o prestigio de forma coactiva. Toda persona es dueña de sus pensamientos, opiniones y declaraciones, y puede pensar y decir lo que quiera acerca de la prostitución. La honorabilidad es una cuestión subjetiva que 
no puede imponerse legalmente. Por otra parte, lo que la mayor parte de la sociedad piense acerca de la prostitución es irrelevante para su carácter ético y no les da derecho a legislar al respecto.

La regulación estatal es mejor que la prohibición, pero no es lo mismo que el ejercicio libre de la prostitución. La regulación gubernamental no defiende derechos sino que los viola: impide el anonimato y la confidencialidad, y obliga a los trabajadores del sexo a pagar impuestos confiscatorios y a participar en el sistema coactivo y fraudulento de la seguridad social. Una mujer que desea dejar de ejercer la prostitución puede naturalmente hacerlo, pero no tiene derecho a utilizar recursos ajenos para recibir formación o encontrar otro trabajo.

La prostitución puede ejercerse en un burdel, en domicilios particulares, en hoteles, o en cualquier lugar con el consentimiento del propietario. El problema de las prostitutas que buscan clientes en espacios públicos como calles, parques o carreteras se debe a que dichos lugares son públicos y su utilización origina conflictos de intereses: unos desean prostituirse y otros buscan prostitución en la calle, otros no desean ver a las prostitutas en sus barrios, cerca de sus casas, sus escuelas, sus parques, sus iglesias o sus comercios. La acotación estatal de zonas donde se permite o prohíbe la prostitución es arbitraria. El propietario de un espacio privado es quien está legitimado para decidir qué actividades son permitidas o prohibidas en el mismo. Quienes deseen vivir en espacios libres de prostitución pueden prohibirla dentro de su propiedad o llegar a acuerdos con otros propietarios.

La prostitución no requiere ninguna formación académica o profesional, por lo cual puede ser una fuente de ingresos para personas sin estudios ni capital. En los países más pobres, las mujeres que viven del sexo pueden ser el principal o el único soporte económico de su familia, y no tienen por qué avergonzarse de ello. Prohibir su actividad implica condenarlas a 
la pobreza o a actividades más duras o menos productivas. La facilidad con la cual una mujer puede utilizarse como prostituta explica que las mafias las exploten como esclavas mediante engaños y violencia.

El problema fundamental de las drogadictas que se prostituyen es la prohibición de las drogas: el aumento de los precios y su marginalización social fomentan que algunas personas recurran a la prostitución para pagar las dosis que necesitan. El problema principal de las inmigrantes ilegales que se prostituyen radica en la violencia y la pobreza de sus lugares de origen, la actividad criminal de las mafias que las secuestran o estafan, y en la dificultad de controlar a los inmigrantes en los lugares de recepción. El turismo sexual es una actividad perfectamente legítima: el cliente viaja a otro lugar para obtener servicios sexuales a mejor precio o de mejor calidad, y las prostitutas locales disponen de más clientes. Recurrir a la prostitución en otros países (o con mujeres extranjeras) no implica colonizarlos, explotarlos, abusar de ellos, despojarles de sus recursos.

Algunas feministas colectivistas quieren abolir la prostitución. No se atreven a aclarar si quieren prohibirla (prohibición es prácticamente sinónimo de abolición) o simplemente que sin coacción legal y de algún modo que no explican deje de existir el intercambio de sexo por dinero. Parece que la prostitución es contraria a la dignidad humana, que denigra al trabajador sexual (generalmente mujer) y lo convierte en una persona de clase inferior. Afirman que pretenden ayudar a las prostitutas diciéndoles que son ciudadanos de segunda. No aclaran si también habría que abolir la pornografía, donde además de sexo y dinero el asunto se exhibe públicamente por más dinero. Insisten en que la prostitución no puede considerarse una profesión porque no es un oficio cualquiera, es la comercialización y compraventa de un cuerpo humano para algo íntimo y personal como el sexo. Ignoran que la prostitución no es la 
venta ni el alquiler de un bien sino la prestación de un servicio. Abominan del lucro, del beneficio y del empresario, les repugna que alguien pueda ganar sucio dinero ejerciendo de intermediario o protector entre prostitutas y clientes. Repiten de forma monótona y machacona sus tópicos y son incapaces de aprender: algunas han dedicado toda su vida a una causa y sería horrible descubrir que ha sido en vano, que no ha tenido sentido porque estaban fatalmente equivocadas.

Algunos conservadores quieren prohibir la prostitución porque según ellos es inmoral. No aclaran si defienden que la moral es obvia, objetiva y universal (y cuáles son todos sus contenidos o preceptos y cómo es posible conocerlos) o si es posible que existan distintas morales en diversos grupos humanos; parecen asumir que si algo es inmoral es legítimo prohibirlo, es decir utilizar la coacción sistemática del estado para castigar a quienes cometan actos inmorales. Inquieren a quienes quieren mantener legal la prostitución (o mejor alegal, apartada de la regulación estatal) si les gustaría que su mujer, su madre o sus hijas (o maridos, padres, o hijos) se dedicaran a ello, como si el hecho de que no te guste algo implique automáticamente que debes intentar conseguir su prohibición.

No está claro por qué debe ser inmoral algo que hace tanta gente desde hace tanto tiempo (la profesión más antigua del mundo) sin agredir a nadie y produciendo beneficios (monetarios y psíquicos) para todas las partes directamente involucradas. Tal vez el moralista es incapaz de entender que lo que a él le parece repugnante en grado sumo a otro puede resultarle interesante o un mal menor que merece la pena a cambio de algo mejor (o un mal no tan menor para el que hay que mentalizarse, bloquearse emocionalmente o incluso drogarse, pero si es la elección libre es la preferencia demostrada, aunque a posteriori pueda haber arrepentimiento). El hombre de bien quizás no tiene en cuenta que si no hubiera prostitutas el deseo sexual de muchos hombres podría dirigirse hacia su madre, su 
mujer, sus hijas u otras potenciales víctimas de seducción o violación. Algunas mujeres pueden sentir miedo ante la posibilidad de que sus maridos obtengan sexo fácilmente (y quizás mejor o más variado) fuera del matrimonio. Algunos puritanos o reprimidos pueden intentar imponer su estrecha moral a los demás de forma coactiva. Algunas personas que quizás disfrutan de poca actividad sexual placentera pueden sentir envidia o rencor por el poder sexual de una prostituta.

La prostitución frecuentemente es una forma de esclavitud y explotación asociada al crimen organizado y a la inmigración ilegal, pero no siempre. Hay prostitutas (pobres o ricas) que ejercen su trabajo libre y voluntariamente. Las que son pobres y no tienen muchas alternativas son tan libres como las menos pobres si nadie las obliga por la fuerza a ejercer. Los prohibicionistas confunden y mezclan todas las situaciones (por interés o incapacidad intelectual), no analizan las diferencias relevantes, y en vez de luchar contra la violencia de las mafias (para lo cual las instituciones estatales son incompetentes) pretenden agredir o acosar a los clientes (y a los empresarios o intermediarios), porque aparentemente son quienes fomentan la prostitución: hay prostitución porque ellos pagan (tautología para la cual sólo hay que conocer la definición del fenómeno analizado).

Efectivamente que haya más clientes dispuestos (demanda) incentiva que haya más prostitutas (oferta). Si se quiere ayudar a las prostitutas libres conviene incrementar la demanda para que puedan subir el precio. Si se quiere eliminar la prostitución que se ejerce con violencia no parece muy acertado utilizar más violencia institucional para prohibir la prostitución voluntaria que se ejerce sin violencia. Si se quiere ayudar a las prostitutas forzadas conviene atrapar a sus agresores y obligarles a que las compensen por los daños causados.

En lugar de luchar contra la pobreza causada por el colectivismo (muchas prostitutas, libres o esclavas, proceden de 
países socialistas) parece que es mejor eliminar los síntomas y las vías de escape. Los colectivistas hablan en nombre de personas a quienes no representan y se refieren a clases, no a individuos. Les preocupa la dignidad de la mujer como colectivo, no el bienestar de cada mujer particular. Asumen que la prohibición ayudaría a la prostituta, no imaginan que podría dañarla marginándola aún más y quitándole una fuente de ingresos más necesarios cuanto más pobre sea y más cargas familiares tenga. Cuando quieren subvencionar a las mujeres para que abandonen la prostitución suele ser con el dinero de los demás. El colectivista insiste falsamente en que la prostitución es un problema y que concierne a todos por igual, hombres y mujeres, prostitutas y no prostitutas, clientes y no clientes. Los igualitaristas que quieren prohibir la prostitución por igualar a hombres y mujeres no exploran la alternativa igualadora de fomentar que más hombres se prostituyan y más mujeres paguen por sus servicios.

Algunas prostitutas y quienes las defienden pretenden que puedan pagar impuestos, sindicarse e inscribirse en la seguridad social: ingenuamente desconocen la auténtica naturaleza del estado o piensan que van a obtener más que lo que tengan que aportar. Algunas prostitutas querrían poder organizarse de forma cooperativa sin intermediarios, pero parece que en este negocio es imprescindible alguien con habilidad y contactos para pagar los sobornos adecuados a policías, jueces y políticos corruptos (aun considerando que la prostitución es muchos lugares no es ilegal).

Prohibir la prostitución puede tener como efecto colateral incrementar su interés (el atractivo de lo prohibido). Además los ciudadanos pacíficos aprenden que las leyes estatales son coactivas y absurdas, por lo cual tal vez se acostumbren a violar otras normas que sí son socialmente funcionales.

La prostitución no es competencia desleal contra las mujeres casadas. Que un cónyuge utilice los servicios de una 
prostituta implica el incumplimiento del deber de fidelidad sexual, con un perjuicio para la parte traicionada, pero el responsable es el cónyuge, no la prostituta, quien no está ligada por ningún contrato con ninguno de los dos cónyuges. Para una mujer puede ser perjudicial que su marido gaste parte de su dinero en prostitutas y que no atienda a sus necesidades sexuales, y para defenderse de ello puede especificar compensaciones contractuales en el pacto matrimonial. Para la mujer suele ser más peligroso que su marido se enamore de otra y la abandone, lo cual es más raro que suceda con una prostituta.

La prostitución infantil (idea que a casi todos seguramente parezca especialmente repugnante) es un complejo dilema ético. No existe ningún límite absoluto no arbitrario que delimite y distinga a los adultos de los niños, y la mayoría de edad legal es un concepto que implica un cambio drástico irreal. Un niño difícilmente decide por sí mismo prostituirse cuando seguramente no conoce el sexo y sus repercusiones emocionales y biológicas. Algunas familias pueden ser tan pobres que prostituir a sus hijos puede significar obtener algún ingreso para no morir de hambre. Obligar por la fuerza a un niño a prostituirse es completamente ilegítimo igual que lo es hacerlo con un adulto.

La relación entre un cliente pacífico y una prostituta forzada por un tercero plantea un problema ético. El cliente tiene una relación sexual no deseada por la mujer, pero es posible que no lo sepa porque aunque se lo pregunte la prostituta puede mentir por miedo a las represalias de quienes la esclavizan. En ciertos aspectos es una situación semejante al receptor de bienes robados o producidos por mano de obra esclava. No es una situación éticamente legítima, pero el cliente no es el causante de la ilegitimidad (aunque tal vez se aprovecha de ella de forma consciente o inconsciente). Si no hubiera ningún cliente los opresores no forzarían a las mujeres a que se prostituyeran, pero eliminar legalmente la demanda de sexo a cambio de 
dinero es prácticamente imposible (la ilegalización de las drogas no elimina su consumo ilegal y agrava el problema); si una prostituta no consigue clientes y dinero para sus opresores seguramente será castigada, por lo cual un cliente es en estas circunstancias un mal menor.

Aunque los razonamientos biológicos de la psicología evolucionista acerca de la naturaleza humana y los argumentos económicos de la praxeología les parecen espantosos e inválidos a los colectivistas que no pueden o no quieren entenderlos (creen que todo es cultura y todo puede cambiarse con el adoctrinamiento estatal adecuado), explicar la desigualdad de hombres y mujeres respecto a la prostitución es relativamente simple.

El sexo es esencial en los seres humanos, organismos vivos preocupados por reproducirse y transmitir sus genes de forma eficiente para ser competitivos en la historia evolutiva. El hombre y la mujer son biológicamente y sexualmente diferentes, no sólo en su anatomía y fisiología sino también en su psicología. Sus estrategias de apareamiento (conductas reproductivas eficientes para la transmisión de sus genes) son diferentes debido a la dispar inversión de recursos como progenitores: el hombre produce fácilmente gran cantidad de espermatozoides y no se queda embarazado, por lo cual es más proactivo y menos selectivo; la mujer sólo produce un óvulo en cada ciclo menstrual y si es fecundado se queda embarazada nueve meses y luego suele querer cuidar de sus hijos, lo que supone un alto coste que explica que sea mucho más selectiva y exigente para el sexo (obviamente los anticonceptivos han cambiado la situación, pero las emociones básicas permanecen porque evolucionaron en un entorno ancestral muy distinto del actual).

El hombre suele tener el poder físico y económico: el hombre es en general físicamente más fuerte que la mujer (resultado de largos periodos evolutivos de lucha entre los machos por las hembras), y a menudo es quien trabaja para otros y quien 
tiene el dinero (resultado de la división evolutiva del trabajo según roles sexuales, el hombre cazaba y guerreaba, la mujer recolectaba y cuidaba de los niños). Pero respecto al sexo es la mujer quien tiene el poder, ya que conoce el deseo del hombre y puede ocultar el suyo (los seres humanos no tienen periodos anuales de celo como otros animales, y las hembras humanas no muestran abiertamente su periodo fértil). La mujer suele pedir algo a cambio de sexo (regalos, compromiso afectivo o legal, dinero), y el hombre tiende a estar dispuesto a ofrecer algo por el sexo. Después del sexo es la prostituta la que se queda con el dinero, mientras que el hombre tuvo un placer psíquico efímero. Mantener relaciones sexuales sin afecto o con alguien no atractivo o repulsivo puede resultar desagradable para la prostituta, pero el hecho de que se haga voluntariamente implica que el dinero cobrado compensa subjetivamente el malestar sufrido. Y si la prostituta disfruta con el servicio sexual entonces su satisfacción es doble. 